Journal of Law \& Social Studies (JLSS)

Volume 3, Issue 2, pp 165-173

www.advancelrf.org

\title{
Benazir Bhutto as an Administrator
}

\author{
Ms. Sumbal Tariq \\ Ph.D Scholar \\ Department of Political Science \\ University of the Punjab, Lahore. \\ Prof. Dr. Iram Khalid \\ Chairperson \\ Department of Political Science \\ University of the Punjab, Lahore. \\ Email: chairperson.polsc@pu.edu.pk \\ Dr. Rehana Saeed Hashmi \\ Associate Professor \\ Department of Political Science \\ University of the Punjab, Lahore.
}

\begin{abstract}
Benazir Bhutto was the first female Prime Minister of a Muslim country. She was also the first politician in Pakistan who was elected Prime Minister twice. Her leadership abilities brought several unique and unprecedented measures in Pakistan. Nonetheless, she had to face a lot of challenges in both of her tenures which included a rift with the Islami Jamhoori Ittehad (IJI) led rule in Punjab that objected her leadership as un-Islamic based on her gender. This rift eventually discontented the President Ghulam Ishaq Khan who dissolved assemblies only two years after she rose to power. Similar issue happened with her government in 1996 when the President Farooq Leghari dissolved the assemblies bringing an end to her second term as Prime Minister and that also two years earlier than its official expiry. Nonetheless, during her both short-lived terms as Prime Minister of Pakistan, she proved herself as a far-sighted leader who made some valuable administrative contributions to the country. Her administration also made some unprecedented measures which were also replicated by the forthcoming governments. This article explores her administrative contributions and it also mentions the challenges she had to face as the first female Prime Minister of Pakistan.
\end{abstract}

Key words: Pakistan People's Party, administrative contribution, women empowerment, democracy, regime.

\section{Introduction}

It is often debated whether great leaders are born or made. The case of Benazir Bhutto entails both scenarios. Benazir Bhutto was the daughter of Zulfiqar Ali Bhutto who was also the former Prime Minister of Pakistan. Mr. Bhutto had also served as the only Civil Martial Law Administrator of Pakistan in 1971. He was also the founder of Pakistan People's Party. Z.A. Bhutto had equipped her daughter with leadership skills. He used to take Benazir on official tours when he was Prime Minister of Pakistan, which enlightened her with experience of dealing with state officials at a very young age. In addition, she was also gifted naturally with exceptional leadership qualities and she also made the use of such attributes to the fullest. She became the first Muslim woman who was elected as the Prime Minister of a Muslim country. Likewise, she was the first Prime Minister who was elected to the office twice. Her first tenure as Prime Minister was viewed as restoration of democracy in Pakistan as she rose to power after the end of an elevenyear rule of General Zia ul Haq.

Despite her charismatic reputation, she had to face several challenges which included a hardliner opposition that spread propaganda against her due to her gender, a lack of cooperation from the Presidents in her both tenures, economic crises of the country, and several other issues. Nonetheless, despite this, she made several contributions through her 
administration and shrewd leadership to Pakistan. This article will highlight these contributions, such as, her peace initiatives with neighboring countries especially with India and Afghanistan when Russian troops were evacuating the Afghan land, her successful negotiations with the IMF which provided loan on convenient terms, her efforts for economic revival and improving telecom and electricity sector, her success in making national institutions like Steel Mills profitable, and efforts for youth building and women empowerment.

\section{Challenges Faced by Benazir Bhutto}

The scenarios in which she rose to power were quite challenging and tough. In fact, throughout her political career, she had to face several hurdles of multiple floras. These include resistance from the Army, stiff opposition, lackluster cooperation from the clergy, poor economic situation of the country, and other administrative problems.

\section{Resistance from the Army}

A major challenge which she faced was the resistance from the Army. Unfortunately, the Army never wanted Pakistan People's Party to come into power. Therefore, Army tried every effort to constrain her party from winning majority in the parliament. For example, it is dominantly said that the Islami Jamhoori Ittehad that won several seats in the 1988 federal elections and majority seats in Punjab Assembly elections was actually backed by the ISI (and thus Army) to gain majority in elections and form federal government to counter Peoples Party's rise to power. Nonetheless, the Army could not become successful in containing her from becoming the popular leader and Prime Minister of Pakistan, as Peoples Party won majority seats by gaining a 38.5\% majority in federal elections in 1988. Despite this, the Army did not like her government and was not pleased with her party. Initially, upon getting influenced by the Army, the President and Chairman Senate Ghulam Ishaq Khan showed hesitance in transferring government to her party, but, after secret negotiations, the power got transferred to her as she agreed to appoint key Army personnel in the Foreign and Defence Ministries.

\section{Propaganda from the Islami Jamhoori Ittehad and the Clergy}

Another challenge was from the clergy due to the political campaign by the Nawaz Sharif led Islami Jamhoori Ittehad (IJI). The IJI propagated a ruling among public that it is not permissible for a woman to be the head of an Islamic state. It is notable to mention here that the elections in Punjab were held three days after the federal elections, and the deep state influenced the elections in the province for paving the way for IJI' victory. Likewise, in Punjab, the image of Benazir was tarnished by spreading vast propaganda against her through pamphlets and wall-chalking, which portrayed her as a foreign agent and anti-national. This propaganda was blindly accepted and followed by many people in Punjab, because the IJI had a stronghold of the politics of the province. Subsequently, the IJI formed the government in Punjab province after winning majority of the seats in Punjab. The propaganda against her attempted to damage her popularity as Punjab was the province with majority of Pakistani population.

\section{Economic Conditions of the Nation:}

The economy was also not in a very good state when she rose to power i.e. neither in 1988 nor in 1993. Unemployment, corruption, fiscal deficit, trade deficit, and IMF loans' conditions were posing major challenges. Therefore, she was required to make appropriate measures to stabilize the economic situation.

\section{Afghanistan's Situation}

In 1988, when she was elected as the first female Prime Minister of the country at the very young age of 35, the superpower Soviet Union was in the process of breaking down into Russian Federation and was withdrawing its troops from Afghanistan. In that situation, she had to act as a wise leader of the nation to foresee the peaceful withdrawal of troops at the Afghan border, because Afghanistan shared a very long porous border with Pakistan. Therefore, this was also a major challenge. Likewise, following the doctrine of strategic depth of Army, she also had to make special and sensitive decisions in her second tenure i.e. 1993 to 1996 when the Taliban were coming to power in Afghanistan.

\section{Her Administrative Measures to Deal with the Challenges}

The way she dealt with all the challenges indicated towards her firm, shrewd, and wise leadership. She also made some notable administrative measures which helped her to counter not only her political hurdles but also national problems. The major administrative contributions by her government are described below. 


\section{Appeasing the Religious Clergy}

In a country where politics in the name of Islam can cause significant insinuations and subversions, it is essential to pacify the clergy especially for a leader or political party that is aiming to establish and extend its regime. As Benazir Bhutto was facing criticism from the clergy due to the propaganda from the IJI, therefore, she first had to mitigate this criticism wisely and politically. To appease the religious leaders, she appointed a prominent religious figure Maulana Siraj ud Din Pun as her advisor. In addition, she arranged Ulema Conventions in all provinces and organized the International Seerat Conference during her tenure. Furthermore, she also reorganized the Islamic Ideological Council, which garnered support from the religious factions. She also provided ease to those going for Hajj as she initiated direct Hajj flights from more than one station i.e. from Lahore too. In addition, her administration also approved the renovation of several mosques in the country.

\section{Pacifying the Army}

To please the army, Benazir Bhutto re-appointed Sahibzada Yaqub Ali Khan as the foreign minister in her government in 1988. Mr. Khan had also served as foreign minister during General Zia ul Haq's regime and as a Military Governor of East Pakistan. Nonetheless, later, she also appointed Tanveer Ahmed Khan as her secretary in the foreign ministry in order to gain some control of the ministry diplomatically.

Benazir Bhutto also put up her efforts for strengthening the National Defence System. She was also adamant in maintaining self-reliance in defence technologies to strengthen the national defence system financially and administratively. For that purpose, she approved several projects to self-sustain Pakistan in its defence technologies. A major initiative was the initiation of airplane manufacturing in Pakistan, which, years after, got turned into the idea of manufacturing of fighter planes in Pakistan. Although, the manufacturing of fighter planes i.e. JF-17 Thunder was started way later, but the idea of such a project was conceived by Benazir Bhutto during her reign.

She was so concerned about strengthening the national defence system that she also included two US manufactured frigates into the NAVY of Pakistan. Likewise, she also visited personally the Siachin glacier region to overview the defence system there. Before her, no Pakistan head of state had visited the region.

\section{Peace Initiatives and Foreign Relations}

The fall of Soviet Union was a historic turnaround of power in international politics. It is pertinent to mention here that this event and the resulting withdrawal of Russian troops started during the first reign of Benazir Bhutto i.e. in 1988. Benazir Bhutto's government oversaw the consequent peace initiatives at the Afghan border. In addition, she also attempted to improve bilateral relations with Russia. Agreements with Russia for construction of new steel mills in Pakistan were signed during her government. This was a historic measure which she took while defying the American political pressure amid the situation when Soviet Union had just fallen.

A major contribution made by Benazir Bhutto was the improvement of bilateral relations with India. She invited Rajiv Gandhi to Pakistan and signed the Non-Nuclear Aggression Agreement with India in 1989 i.e. soon after she rose to the Prime Ministerial position. This agreement entailed that neither of the two countries can wage an attack or assist a proxy attack on the nuclear facilities of each other. This historic agreement developed a new pathway of peace and a ray of bilateral positive relations between India and Pakistan in South Asia. It also reflected her leadership qualities and skillfulness in making peace in the region.

Pakistan also hosted SAARC Conference during Benazir Bhutto's first tenure i.e. in 1988. This was a historic achievement as it extended positive image of Pakistan. The leadership of all SAARC countries including that of India visited Pakistan during her first tenure to participate in the conference, which resulted in improving bilateral relations with India and with all South Asian countries.

In addition, Benazir Bhutto was the prime minister who brought Pakistan back into the list of Commonwealth nations, which produced perks of this membership to Pakistan. For example, her efforts brought away Pakistan from isolation in international politics and resulted in improving its foreign relations with commonwealth nations.

\section{Freedom of Press}

Benazir Bhutto gave a lot of value to the principles of freedom of speech and freedom of expression and regarded them as the fundamental human rights. To ensure the provision of such basic human rights, she also granted enough freedom to the media. Earlier on, there were a lot of restrictions on the media which were applied during the dictatorial 
rule of 11 years of dictatorial rule by General Zia ul Haq. Benazir Bhutto abolished all such laws that were putting restrictions on freedom of speech and freedom of expression of media. This led to a revival of media in Pakistan. The entertainment industry also started flourishing as a result of such initiatives of lifting restrictions on media. She also established a Peoples Network Program, which led to the start of new TV channels in Pakistan.

A prominent example of curbing of black laws of restrictions on media is the abolishment of Newsprint Quota System. This law was being used by the previous governments as an instrument to suppress media by blackmailing them. Essentially, she privatized the National Press Trust which ended the control of the government on the print media.

In addition, she also reinstated all those journalists who got banned or got fired from media agencies by the previous government due to sharing news or expressing their stance on a political issue. She also ended the blacklisting of several journalists and writers who were affiliated with news media agencies or with Radio or TV channels. This gave freedom to the writers to publish truth without the fear of getting banned from the media. Benazir not only restored the right of freedom of speech and expression for the journalists and writers but she also gave freedom to the opposition parties and their spokespersons to express any criticism or comment their stance about any endeavor of the government or about any national or regional issue without any political pressure.

A major step she took was to lift the requirement for journalists to take a NOC from government for visiting abroad. Thus, journalists could freely visit any foreign country for any of their journalistic or private endeavors. Such freedom was not given by the previous government of General Zia. Hence, she adopted a non-discriminative policy entailing freedom for press irrespective of whether a news agency expressed dissent or disagreement to any of her political measures.

\section{Efforts to Curb Drugs}

It is noteworthy to mention here that Benazir Bhutto also advocated actively for curbing of drugs. A major initiative she took in her government was to completely eradicate the cultivation of poppy and the closure of around 12 Heroine labs in Pakistan. Furthermore, she also added a new ministry of anti-narcotics in her cabinet. Likewise, she also promoted the establishment of nationwide recovery units for the rehabilitation and cure of drug addicts. Her efforts led to a significant reduction of smuggling of drugs in Pakistan and particularly, in banning poppy cultivation and trafficking in the region.

\section{Economic Measures}

Benazir Bhutto implemented several measures to revive the economy. A major intention of such initiatives was to invite investment from the private sector as well as from foreign investors. It is pertinent to mention here that the several initiatives of Benazir Bhutto such as her efforts to bring investment from the private sector and foreign investors, her peace initiatives with India, her successful negotiations with the IMF and resulting relaxed conditions of the IMF on loan payments on Pakistan, her freedom to the press, etc. brought a positive outlook of Pakistan at the international level. This eventually caused a positive impact on the national economy as, for instance, it boosted the Karachi Stock Exchange that observed a significant rise during the tenures of Benazir Bhutto.

\section{Investment in Private Sector}

Benazir also formulated such policies which attracted foreign direct investment. For example, in September 1994, i.e. during her second tenure, she signed agreements with US businessmen which lead to a pledge of around $\$ 4$ billion as investment in private sector in Pakistan. Similarly, in the same year in December, her government signed additional eighteen agreements with US private investors which were worth of investment of around $\$ 2.5$ billion. Toyota founded a manufacturing plant in Pakistan with an investment of around 580 million Rupees. This plant produced around 10,000 vehicles annually. Such initiatives also produced jobs for laborers in Pakistan. In addition, her government actively took part for privatization of poorly performing state-owned institutions. For example, $10 \%$ privatization of Pakistan Telecommunications Corporation (PTC) brought $\$ 900$ million investment from the private sector. Likewise, the deregulation of airline sector resulted into creation of five new private airlines.

\section{Increase in Foreign Aid}

As Benazir's government came after the end of the dictatorial rule of General Zia ul Haq, the world saw her rule as restoration of democracy in Pakistan. Therefore, this democratic image building of Pakistan in her rule invited a 22 percent increase in foreign aid for Pakistan with the intent of succession of continuation of democracy in the country. 


\section{Successful Negotiations with the IMF}

Another prominent involvement of Benazir Bhutto was her skillful negotiations with the International Monetary Fund (IMF). Having the educational qualifications from Oxford and Harvard, Benazir negotiated so successfully that the IMF issued an additional $\$ 100$ million alongside the approved $\$ 1.2$ billion on relaxed terms in 1989 . Unfortunately, her government ended prematurely in 1990 and the relaxed terms of conditions of IMF could not be fulfilled, which led to strictness in conditions for later governments for additional loans.

\section{Measures for Ease of Doing Business}

In order to encourage investments from the private sector, the PPP government under her regime eased up restrictions and regulations of doing business in Pakistan. For this purpose, she stabilized the import-export policy and lowered regulatory pressures on investors and exporters. The purpose of this initiative was to increase the balance of payment and reduce the trade deficit.

To further improve and monitor the impact of her efforts to invite investment from the private sector and from abroad, she also established an Investment Board and became the chairperson of the board. The board oversaw the ease of doing business in the country and reduced restrictions in investment for the private sector. In addition, it also issued licenses for launching new industrial units. Nine free trade zones were also established in 1994: three in Punjab, three in Sindh, two in NWFP (KPK now), and one in Azad Kashmir.

Another key measure which Benazir Bhutto took was to lift the ban on import of Gold. Earlier on, this ban was imposed to curb corruption by the previous government. However, Benazir Bhutto ended that ban which invited Gold imports by private stakeholders to Pakistan. This initiative was intended to increase the overall amount of Gold in the country.

\section{Improving Telecom Sector and Communication Network}

In order to provide facilities to the investors and to the public, Benazir Bhutto's government wanted to ensure a quickened communication network in the country. For this purpose, her administration introduced the Direct Dialing System in several urban regions in the country. Likewise, 64,400 new telephone lines and 99,391 new telephone connections were installed during her tenure. In addition, she also opened new 445 offices of Post Office of Pakistan in the country in order to quicken the pace of communication through the Pakistan Post.

\section{Improving Electricity Conveyance}

A major requirement for the industrial sector especially for the textile sector was to ensure adequate availability of electricity. Therefore, she devised a strategy to completely end load shedding within three years from the country. However, she could not implement that strategy as her government was soon overthrown, and the load-shedding could not be ended completely. Nonetheless, her administration implemented certain special measures which improved the conveyance of electricity in the country.

A great achievement of her government was to bring electricity to around 4000 villages in a year. This brought electricity to around 600,000 households in one year. Furthermore, she mandated the electricity providing companies to ensure the installation of new electric connections within 30 days in the urban areas and 45 days in rural areas. Her goal was to bring electricity to every household. In addition, she also approved the computerization of electricity billing in order to curb corruption in billing. This was an unprecedented measure taken by a government in Pakistan. Her strict regulation of the electricity providing departments also resulted into reducing electricity theft that was recorded the lowest during her tenure. Furthermore, as she was keen to bring investment from the private sector, therefore, she also invited investment into the power sector in order to strengthen her resolve of providing electricity to every household by gathering resources for the electricity providing department of government.

\section{Creating Employment Opportunities}

To generate employment opportunities, her government approved the establishment of micro-channels to connect Karachi with Peshawar, which opened the job opportunities for more than 4000 mid-career workers.

\section{Making National Assets Profitable}

Benazir wanted to make national assets profitable. She intended privatization only for those assets which were not making any profits. Therefore, she first tried to improve policies and management of key national assets to make them 
profitable and to not privatize them. For example, her government improved the operations of the Pakistan Steel Mill. Her government also made substantial investment into the Steel Mill as well as in Heavy Mechanical Complex and in Heavy Electrical Complex in order to make them profitable.

She also wanted to generate employment opportunities for people. Therefore, she introduced several measures to realize this. For instance, she reopened the Baluchistan Textile Mills that produced 5000 jobs for textile workers. Earlier on, the Mill was closed in 1983 during Zia's regime. Her government also approved the expansion of Port Qasim at Karachi, which led to generating new employment opportunities.

\section{Oil and Gas Exploration}

Benazir Bhutto also actively supported the efforts for exploration of oil and gas in country, which produced positive results. For instance, 10 new oil fields were discovered in Pakistan in one year, which led to an increase of 22 percent in the national production of oil and gas in Pakistan and an unrestricted supply of natural gas to domestic and industrial consumers.

\section{Reduction of Government Expenditures}

A major initiative carried out by Benazir Bhutto was to reduce the non-development expenditures of the government. This was followed with adopting austerity measures at the ministerial level. This measure was essentially needed due to the dire economic condition of the country. Nonetheless, as her government has granted significant amount of freedom to the press, therefore, she could not prevent the propaganda from the opposition political parties regarding expenditures and corruption allegations against her.

\section{Opportunities for Youth}

Benazir was also keen to generate opportunities for the youth. Therefore, to steer appropriate policy options for the youth, she formed a new ministry to mitigate the problems of youth and to generate opportunities for the youth. This was the first time that a separate ministry for youth was established.

Likewise, her government administration also facilitated the establishment of around 60,000 new literacy centers for the youth. In addition, she also exerted her efforts for employment of youth in overseas markets. Another major contribution to offer employment for the youth was to induct 50,000 youth as schoolteachers which served as a key service in employing the educated youth in the sector of education. Likewise, her government built 46000 new schools. Likewise, her government also facilitated opportunities for the youth to acquire loans at convenient terms for their education or for entrepreneurial ambitions. This indicates towards her comprehensive planning for the development of national youth.

\section{Women Empowerment}

Benazir Bhutto also made special efforts for the empowerment of women. She established a separate ministry for women to address the concerns of women. In addition, she added at least five women as ministers into her cabinet. In addition, she had also established a separate ministry to deal with the issues of women and to carry out measures for women empowerment. In order to help the poor women, she distributed free sewing machines among poor women especially among widows so that they could earn livelihood for themselves. She also issued monthly stipends for widows. This idea was later got translated into the Benazir Income Support Programme by her husband Asif Ali Zardari during his Presidential tenure.

\section{Charter of Democracy}

A remarkable act under the belt of her achievements is her efforts in signing the charter of democracy with PML-N leader Nawaz Sharif for the restoration and strengthening of democracy in Pakistan. This charter also led to the completion of first five years tenure by any democratically elected government in Pakistan. Since the signing of this agreement the incoming two governments of PPP and PML-N have completed their 5 years tenure and the third one i.e. the current government of PTI is on its way to achieve that. Earlier than that, no democratically elected government has been able to achieve this feat, because either it was thrown by the army or it faced such backlash from the opposition parties that the President had to dismiss the government. Even the strongest and most popular government of Zulfiqar Ali Bhutto could not complete the five years tenure. This indicates the strength of the political contribution made by the former PPP chairperson Benazir Bhutto in restoration and solidification of democracy in Pakistan. 


\section{Conclusion}

In a nutshell, Benazir Bhutto was an inspiring leader who became the ray of hope for restoration of democracy in Pakistan after the 11 years rule of dictatorship. Her efforts also led to the signing of the Charter of Democracy that resulted into inviting cooperation among the major political parties of Pakistan for strengthening of democracy. Benazir Bhutto was also the first every woman who was elected as Prime Minister of a Muslim country. Likewise, she was also the youngest Prime Minister of Pakistan and she also holds the notable achievement of being the first politician who got elected as the Prime Minister of Pakistan twice. Benazir Bhutto was gifted with leadership qualities as inheritance from her father Zulfiqar Ali Bhutto. Likewise, she also got the chance of touring several countries and meeting with their leaders as her father used to take her with him on his official state's visits. This instilled a tremendous amount of experience into her about dealing with international political leaders. Furthermore, she was a graduate from Oxford University and had an educational qualification from the Harvard University; such rich academic background made her even more capable to run the leadership of Peoples Party and also the affairs of the state.

Benazir had to face several challenges in her political career. The first challenge was to become the leader of People's party in the presence of powerful politicians in the party, which she countered through her charismatic leadership skills. After taking over the party, the next challenge was the resistance from the Army. The Army never wanted Pakistan People's Party to come into power. Therefore, they tried everything to contain the popularity of People's Party. In that regard, they established the Islami Jamhoori Ittehad (IJI) under the leadership of Punjab born politician Mian Nawaz Sharif. The IJI launched a massive propaganda against her maintaining that there is no evidence in Islam to accept a woman as a ruler and therefore, the vote must not be given to Benazir. Thus, the IJI instigated opposition of clergy against Benazir. The IJI also portrayed herself as a foreign and anti-national agent. Such propaganda costed her party the government in Punjab. Another major challenge was the dire state of the economy, which had to be dealt wisely.

In order to counter the challenges, Benazir Bhutto adopted the methods of diplomacy and peaceful initiatives and carried out several administrative measures which appeared effective in the beginning to mitigate the challenges. For example, she appointed a popular religious leader as her advisor and organized several religious conferences to end the criticism from the clergy. Then, she also appointed the same politician as her Foreign Minister i.e. Sahibzada Yaqub Khan who was serving at the same position during Zia ul Haq's regime.

Benazir Bhutto also held successful negotiations with the IMF which generated loan on easy terms. Her accession to power was also regarded as an instance of restoration of democracy in the country, which portrayed a positive image of her rule and of Pakistan. This positive image building resulted in increasing the foreign aid by $22 \%$ during her rule. It also impacted positively on the economy, for instance, by improving Stock Exchange. Likewise, she performed several measures such as improving the ease of doing business in Pakistan, inviting foreign direct investment especially in the automobile, energy (electricity), and telecom sectors. Her administration improved the conveyance of electricity and the telecommunication department by extending the network of electricity and telephone connections to villages too. In addition, her administration also improved ease of doing business by reducing restrictions for traders, especially for exporters. Furthermore, her government also improved the investment from government in national assets such as in Pakistan Steel Mills and Heavy Mechanical Complex. These institutions were incurring huge losses before her government.

In sum, it can be asserted that, although, Benazir Bhutto had to face a lot of challenges in terms facing resistance from Army and clergy, nonetheless, she managed to provide effective economic plans and setup a judicious government through her apt leadership. Unfortunately, the deep state, the opposition from Islami Jamhoori Ittehad, the rift with Punjab government and with President Ghulam Ishaq Khan in her first tenure and with Farooq Leghari in her second tenure, led to the premature dissolution of her government. Despite not being in power, Benazir has been regarded as a fierce opposition leader whose opposition kept the ruling party in check. In addition, the Charter of Democracy is another gift from her despite she was not in power when the charter was signed. These instances indicate that she was an able administrator and a competent leader.

\section{References:}

Ahmed, M. An Economic Crisis State? In, Maleeha Lodhi (Ed.). (2012). Pakistan Beyond the Crisis State. Oxford University Press. 
Annex III, Charter of Democracy. In, The Decade of Democracy in Pakistan. Friedrich-Ebert-Stiftung, Pp. 132.

Ayoob, M. (1972). Profile of a Party: PPP in Pakistan. Economic and Political Weekly. Vol. 7, No. 5/7, Annual Number (Feb. 1972), pp. 215+217-219.

Azeem, M., Ahmad, M., \& Tabassum, T. (2019). A Sneaking Exposure to Premiumship through Politics of Tactics and Compromises - Civil Military Relationship during Benazir Bhutto's Government 1988-90. Pakistan Social Sciences Review. Vol. 3, No. 1 [663-672], at 670.

Azeem, M., Chishti, Q., Rifat, F., Serfraz, A., \& Khan, S. O. (2020). Studies in Female Leadership in Pakistan: Benazir Bhutto. JRSP. Vol. 57, Issue 4 (Oct-Dec 2020).

Aziz, S. (2017). A Leaf from History: Pakistan's chequered association with the Commonwealth. DAWN.

Aziz, S. (2016). The 'dawn of a new era' that remained a dream. DAWN.

Boquerat, G. (2015). Pakistan's power game and the new media landscape. In, Kalia, R. (Ed.). Pakistan's Political Labyrinths: Military, society and terror. Routledge.

Braithwaite, R. (2011). Afgantsy: The Russians in Afghanistan 1979-89. Oxford University Press. Pp. 281.

Business Recorder. (2015). Shaheed Benazir Bhutto's Achievements as the Prime Minister of Pakistan. Business Recorder. Retrieved from: 〈https://fp.brecorder.com/2015/12/201512291260032/>

Clinton, W. J. (11-April-1995). The President's News Conference with Prime Minister Benazir Bhutto of Pakistan. The American Presidency Project. Accessed at: <presidency.ucsb.edu/documents/the-presidents-newsconference-with-prime-minister-benazir-bhutto-pakistan>

Dawn. (2007). Business often sides with military. Dawn.com

Editorial. (2012). Saute-e-Niswan - The Voice of Women. National Commission on the Status of Women. Issue 7, page 1.

Girardet, E. (1988). In Afghanistan, drug trade is blooming. Heroin production in Asia's 'golden crescent' worries drug officials. The Christian Science Monitor.

Grabovac, D. (2005). Are Leaders Born or Made? Regent College.

Haeri, S. (2020). 5 - Benazir Bhutto: A Queen “Without Parallel”, in, The Unforgettable Queens of Islam. Cambridge University Press. See also the same chapter in: Succession, Authority, Gender, pp. $141-182$.

Haider, Z. Ideologically Drift, in, Lodhi, M. (2012). Pakistan Beyond the Crisis State. Oxford University Press. p. 124-127.

Hughes, R. \& Shaffer, R. (2021). The Bhutto family and Pakistan: power, politics, and the deep state. Intelligence and National Security, Vol. 36, Issue 6. Pp. 925-936.

Husain, S. I. (2019). Benazir Bhutto and freedom of press. Daily Times.

Kamran, S. (28-Dec-2019). Remembering the Indelible Benazir Bhutto. Daily Times.

Kamran, S. (2020). The legacy of the great Benazir Bhutto. Arab News.

Khoja, K. (1998). Confidence-Building between India and Pakistan: Lessons, Opportunities, and Imperatives. Stimson.org

Naden, C. J. (2011). Benazir Bhutto. Marshall Cavendish. at pp. 31-32.

Naazer, M. A. (2018). SAARC Summit Diplomacy and Its Impact on Indo-Pakistan Relations (1985-2014). FWU Journal of Social Sciences, Summer 2018, Part-1, Vol.12, No.1, 67-75. at P. 70.

Parveen, S. \& Bhatti, M. N. (2018). Freedom of Expression and Media Censorship In Pakistan: A Historical Study. Journal of Historical Studies. Vol. IV, No. II (July-December 2018), Pp. 01-21, at 14.

Schaffer, H. \& Schaffer, T. C. (2016). Sahibzada Yaqub Khan, 1920-2016: The end of an era. Brookings.edu

Shafqat, S. (1996). Pakistan under Benazir Bhutto. Asian Survey, Vol. 36, No. 7 (Jul. 1996), pp. 655-672. University of California Press. https://doi.org/10.2307/2645715 
Shaikh, M. A., Sahito, Z. H., \& John, S. (2020). Role of Benazir Bhutto in Restoration of Democracy in Pakistan (1977-1988). Global Political Review, V(I), 260-268. doi:10.31703/gpr.2020(V-I).29

Shafique, M. A. (2020). Politics of Zulfikar Ali Bhutto. Forman Christian College.

Shoaib, M. (1996). Sweet Sounds of the Bazaar: Pakistan's Efforts to Lure Foreign Investors. Northwestern Journal of International Law and Business. Vol. 16, Issue 3, at pp.516.

Sekine, K. (1992). Benazir Bhutto: her political struggle in Pakistan. University of Massachusetts Amherst. Masters Theses 1911 - February 2014. 2457.

Weiss, A.M. (1990). Benazir Bhutto and the Future of Women in Pakistan. Asian Survey. Vol. 30., No. 5. University of California Press.

U.S. Government. (1995). 1995 Compilation - Presidential Documents. In, The Code of Federal Regulations of the United States of America. US Government Printing Office. Washington. 